\title{
CYTOMORPHOLOGICAL AND MORPHOMETRIC STUDIES OF SOMATOTROPHS IN THE PITUITARY PARS DISTALIS OF POSTNATAL FEMALE ALBINO RATS
}

\author{
TAGHREED M. NABIL \\ Department of Cytology and Histology, Faculty of Veterinary Medicine, Beni-Suef University
}

Received: 31 December 2015; Accepted: 31 January 2016

\begin{abstract}
The present study was designed to demonstrate the cytomorphological and morphometric changes of somatotrophs in female rats during the postnatal period by using the light and transmission electron microscopy. Fifty female rats were used in this study which classified into age ten groups ( 5 animals / group) (neonate, 7, 15, 22, $30 \& 40$ days-old rats); adults (2, 4 \& 6 months-old rats) and senile (2 years-old rats). All animals were sacrificed and their pituitary glands immediately dissected, fixed and processed for light and electron microscopy. At the first week of postnatal life, somatotrophs were scanty and showed signs of inactivity. They were revealed as sporadic, small-sized round or triangular-shaped cells with faint yellow stained cytoplasm after staining with PAS-Orange G. Ultrastructurally, it showed few secretory granules and ill-developed cytoplasmic organelles. With age, a significant increase in the number of somatotrophs associated with increasing in the secretory activity and organelles at the immature stage till reaches its maximum in adults. At 22-30 days-old rats, two types of somatotrophs were seen ultrastructurally; densely granulated and sparsely granulated type. No significant change in the number of somatotrophs was observed at the pubertal stage and most of somatotrophs appeared in the storage phase exhibiting by heavily granulated cytoplasm with ill-distinct organelles. While in senile rats, a significant decrease in the number of somatotrophs that exhibited signs of inactivity was observed. They showed some regressive changes including vacuolated cytoplasm, decreasing in granulation with degenerated organelles. In conclusion, there was a significant postnatal age-related change in the structure and number of somatotrophs in female rats.
\end{abstract}

Key words: Somatotrophs, ultrastructure, morphometry, postnatal, female rats.

\section{INTRODUCTION}

The anterior pituitary gland is considered a key regulator of body homeostasis during the development (Müller, 1999). It is a dynamic and complex endocrine gland that synthesizes and secretes trophic hormones from distinct endocrine cells (Lee, 2006). Somatotrophs secrete growth hormone considered as a primary regulator which plays an important role in body growth and metabolic hemostasis (Anderson et al., 2004). Somatotrophs constitute about $40-50 \%$ of cell population in anterior pituitary gland located mostly at the lateral regions (Melmed, 2002). Structural and morphometrical changes in the pituitary gland may be caused by age and could influence the change in cell density and total cell number of somatotrophs (Shimokawa et al.,

Corresponding author: Dr. TAGHREED M. NABIL

E-mail address: tagh_mhm@yahoo.com

Present address: Department of Cytology and Histology, Faculty of Veterinary Medicine, Beni-Suef University.
1996). The number of somatotrophs increased with age from suckling to adulthood in female mice (Sasaki, 1988) and reduced growth hormone level caused by reduced somatotroph cell population leading to dwarfism (Garcia-Tornadu et al., 2010). The relative proportions of somatotrophs and lactotrophs showed a clear variation between sexes in the anterior pituitary gland of rats (Takahashi and Kawashima, 1982). The hypothalamus and sex glands are responsible for this difference during the postnatal life (Sasaki and Sano, 1986). Aging produces alterations in certain functions of the hypothalamo- pituitary axis resulting in sexually dimorphic changes in the somatotrophs (Jurado et al., 1998). Structural and morphometric data concerning the age-related changes of somatotrophs, especially, in females are scarce. Therefore, the aim of this study was carried out to investigate the normal age-related changes on the cytological, morphometric and histochemical characteristics of somatotrophs in female albino rats (from birth to senile ages) with the aid of light and transmission electron microscopy. 


\section{MARTIALS AND METHODS}

The present work was conducted on 50 female albino rats which obtained from Helwan Laboratory Breeding Animal Farm. They were classified according to postnatal ages (5 animals of each age) into: neonates (at birth '0 day', 7 days-old rats); immature $(15,22,30$ days old-rats); pubertal (age of vaginal opening; 40 days-old rats); adults (2, 4 \& 6 months old-rats) and senile (2 years old-rats). In adult females, vaginal smears were examined daily to achieve diestrous smears and only animals with normal and regular estrous cycles were used. All rats of different ages were killed by over dose of ether inhalation. Pituitary glands were quickly dissected and fixed in Bouin's fluid. The samples were subjected to classical histological procedures of dehydration, clearing and paraffin embedding \& 4-6 $\mu \mathrm{m}$ thick sections were obtained and stained with hematoxylin \& eosin stain. For demonstrating somatotrophs, pituitary sections were stained with PAS-Orange $\mathrm{G}$ technique (Bancroft and Gamble, 2008).

For electron microscopy, some specimens were cut into very small pieces and fixed in $4 \%$ gluteraldhyde in phosphate buffer solution, washed in the same buffer (Hayat, 1986), post-fixed in 1\% osmium tetroxide then embedded in epoxy medium. Semithin sections were obtained and stained with toluidine blue then examined by light microscope (Richardson et al., 1960). Ultra-thin sections were obtained, mounted on copper grids, contrasted with $5 \%$ uranyl acetate and stained by lead citrate (Reynolds, 1963) and examined by a JEOL transmission electron microscope (JEM-1400 TEM $80 \mathrm{kv}$ ) in the electron microscopical unit of Assuit university.

\section{Morphometric analysis:}

The counting the somatotrophs in different ages of female rats was done manually by using Image - J $\mathrm{v} 1.45 \mathrm{~s}$, free software version for image processing and analysis in Java, under an binuclear research microscope (Leica, Hannover, Germany) attached with digital camera (Canon, Tokyo, Japan). Ten non overlapping fields of each section of the pars distalis stained with PAS-Orange $\mathrm{G}$ were randomly selected at different levels (ventral, medial, and dorsal) and images were captured at 400x magnification.

\section{Statistical analysis}

Statistical analysis was performed on SPSS package Version 20. Data were presented as the Mean \pm SE. Differences among the study groups were detected by one way analysis of variance (ANOVA) and post hoc comparisons were made by LSD test. $P$ values < 0.05 were considered statistically significant.

\section{RESULTS}

\section{Light and ultrastructural results:}

During the first week of life (0-7 days-old rats), somatotrophs were rarely to be recognized and sporadically distributed between other cells. They were oval, rounded or triangular shaped cells with lightly acidophilic cytoplasm (Fig.1). Their nuclei were large, spherical, vesicular and eccentrically located. Some cells showed mitotic figures. With PAS-Orange $G$ staining method, they had faint yellow cytoplasm (Fig.2). Ultrastructurally, they contained few round electron-dense secretory granules that peripherally distributed uniform, and large euchromatic nucleus. Most of cytoplasmic organelles were poorly-developed (Fig.3).

At 15 days-old rats, somatotrophs were slightly increased in number than that observed at the first week of life. While this cytoplasm appeared to be more condensed and more deeply stained (Fig.4). Ultrastructually, the secretory granules increased and appeared to be filling the majority of the cellular cytoplasm. Some of cytoplasmic organelles such as mitochondria and RER saccules appeared welldeveloped. The nucleus showed euchromatic chromatin and two prominent nucleoli (Fig.5).

At 22-30 days-old rats, marked increasing in the number of somatotrophs were recognized. They arranged mostly in groups or cords surrounding the blood sinusoids. Some of them appeared granulated with deeply stained cytoplasm while others were degranulated with faintly stained cytoplasm after PAS-Orange G staining (Fig.6). The electron microscope showed two types of cells; sparsely granulated and densely granulated type (Fig.7). The sparsely granulated cells showed an electron-lucent cytoplasm with numerous well-developed organelles as dilated cisternae of RER, mitochondria. While the granulated ones were characterized by electron-dense cytoplasm, numerous of secretory granules accumulating at one pole of the cell that associated with few organelles. Both cell types were shown to face the blood capillary.

At 40 days-old rats (pubertal age), somatotrophs appeared to be distributed all over the pars distalis that either singly or in clusters. Most of the examined cells appeared granulated and contained deeply stained cytoplasm (Fig.8). Ultrastructurally, the cytoplasm appeared packed with electron-dense secretory granules that intermingled with few organelles. The sparsely granulated cells were rarely to be seen in microscopical fields (Fig.9).

With advancement of age (2-4 months-old rats), the somatotrophs were more numerous than that observed in previous ages. Most cells were large with pale yellowish cytoplasm containing large, rounded 
vesicular nuclei (Fig.10). With electron microscope, they appeared sparsely granulated with electronlucent cytoplasmic matrix. Few secretory granules were accumulated near the plasma membrane. Numerous mitochondria and well developed dilated cisternae of RER were seen. The nuclei were rounded and had euchromatic chromatin which surrounded by a well-defined nuclear membrane (Fig.11). No cytological changes in the somatotrophs were noticed at 6 months-old rats.

With advancing of age (2 years-old rats), the examined pars distalis of senile rats showed decreased number and size of somatotrophs compared to the adults. They lost the typical structure and showed vacuolated cytoplasm and illdistinct cell boundaries. Some cells were seen to be destroyed (Fig.12). Ultrastructurally, the cytoplasm had few, small sized secretory granules and degenerated cytoplasmic organelles which included highly dilated, destructed RER, swollen mitochondria and irregular nucleus (Fig.13).

\section{Morphometric results:}

Relations of the number of somatotroph cells detected in the postnatal ages of female rats are summarized in (Table $1 \&$ Fig.14). The number of somatotrophs showed a significant increase with progressing of age from $7,15,22,30$ days-old rats compared with neonate rats. No significant changes were recorded in the number of somatotrophs between ( $30 \& 40$ days \& 2 months-old rats), after that time the number increased significantly to reach its maximum at adults (4 months \& 6 months-old rats) compared with rats at birth. Marked significant decrease in the number of somatotrophs was seen in senile rats (2 years old-rats) compared to the other ages except at 15-days old rats with no significant.
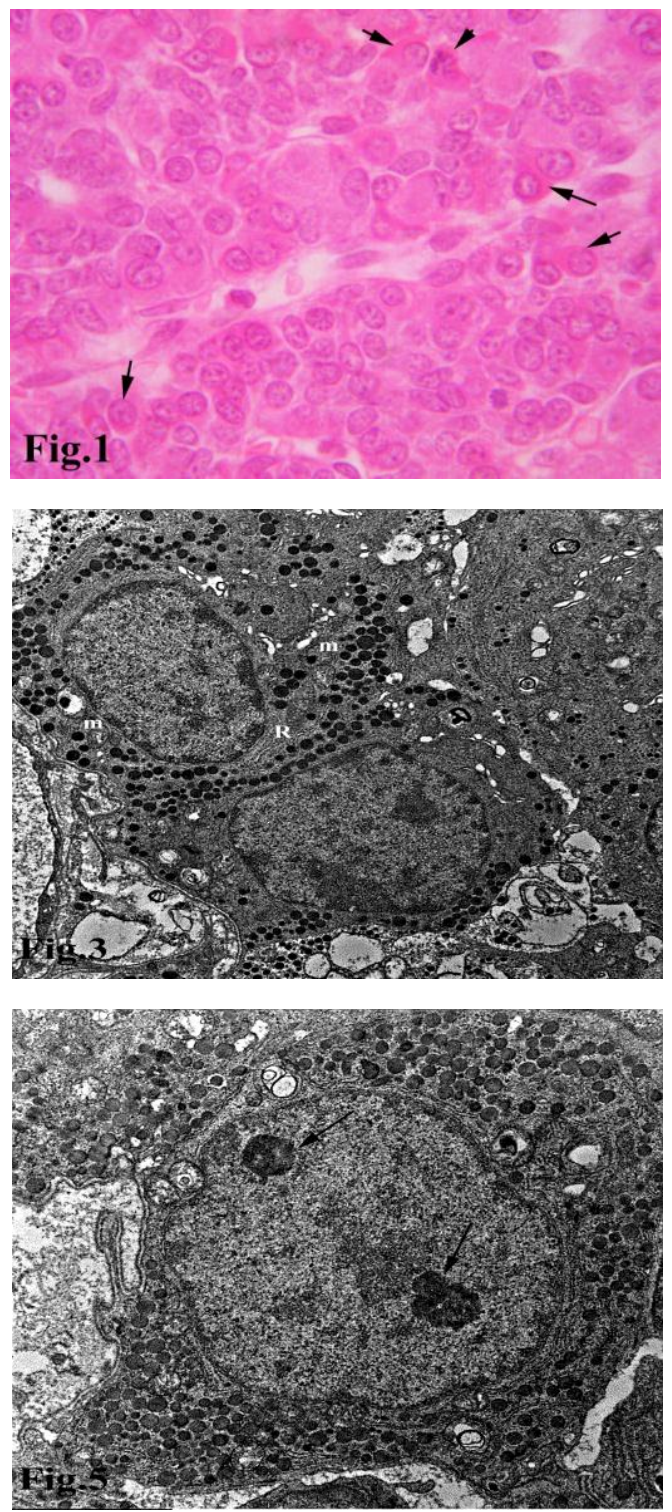
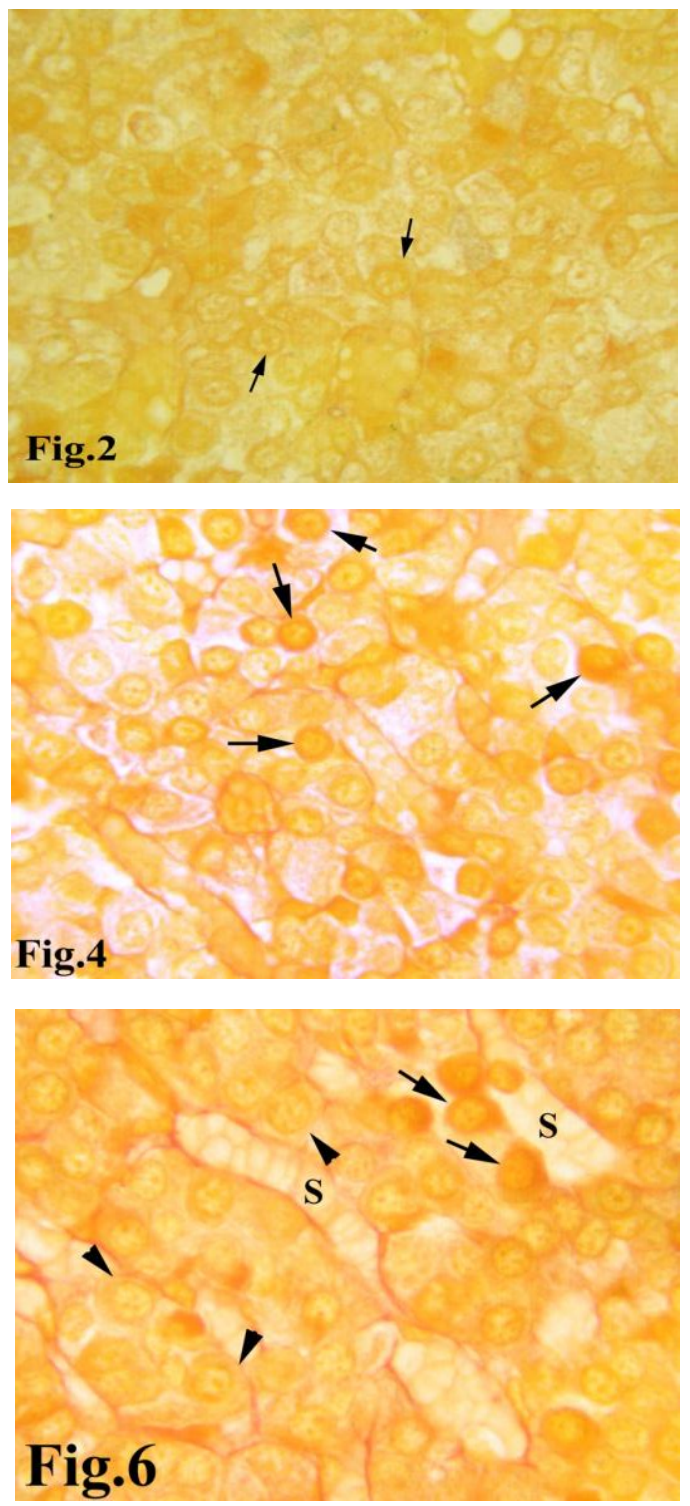

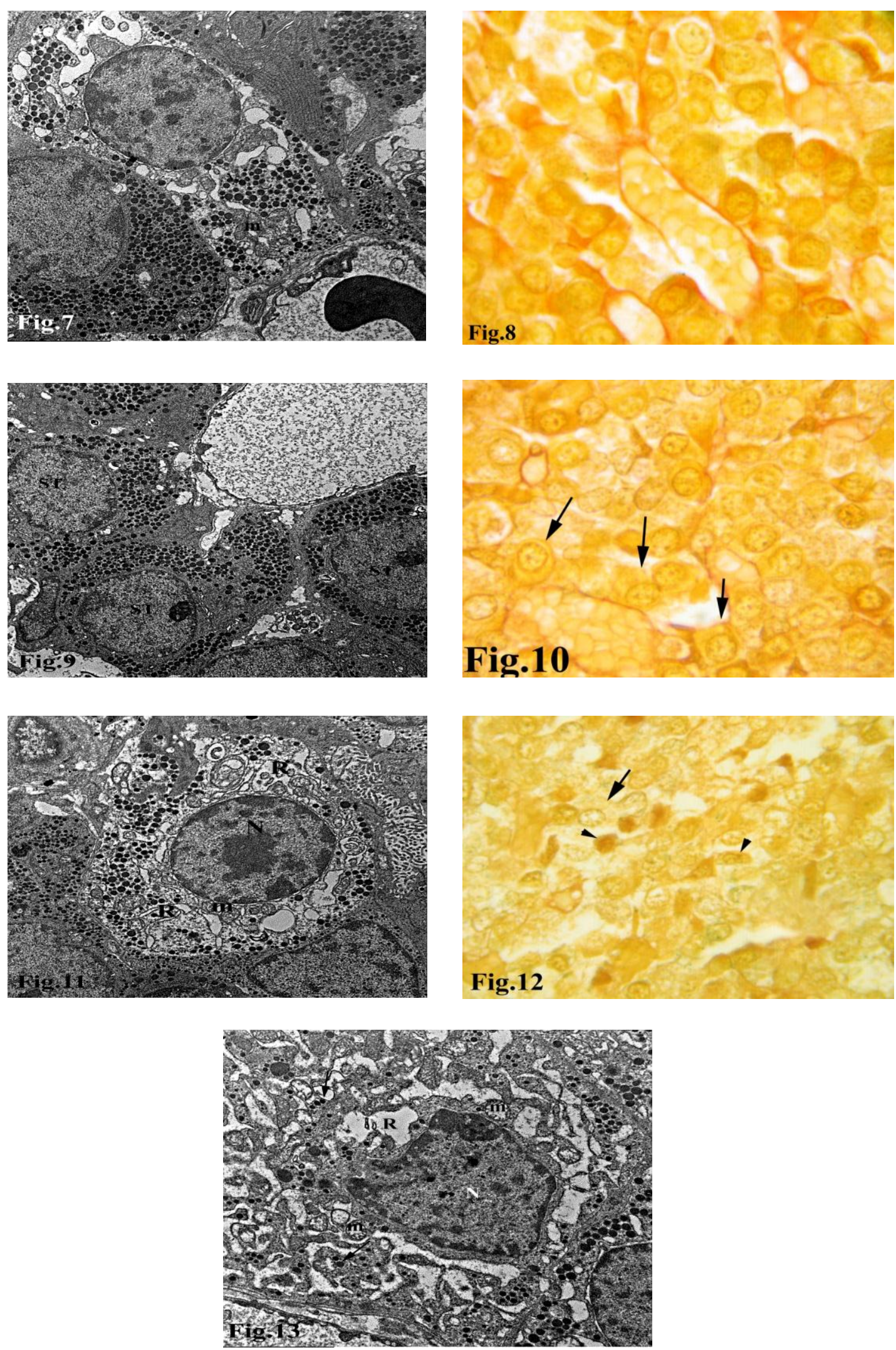


\section{LIST OF FIGURES}

Fig.1: A photomicrograph of pars distalis of female rat at birth showing few, sporadic, small-sized, oval or triangular-shaped somatotrophs with large rounded, vesicular nucleus (arrows) and mitotic figures (an arrowhead). H\&E, X1000

Fig.2: A photomicrograph of pars distalis of female neonates at 7 days- old stained with PASOrange $G$ showing somatotrophs with faint yellow cytoplasm (arrows). X1000.

Fig.3: An electron micrograph of somatotroph cells of neonates at 7 days-old female rats showing electron dense cytoplasm with few uniform rounded, electron dense secretory granules, few delicate RER canaliculi $(\mathrm{R})$, rounded mitochondria $(\mathrm{m})$ and euchromatic nuclei $(\mathrm{N})$. X8000.

Fig.4: A photomicrograph of pars distalis of 15 daysold female rats stained with PAS-Orange G showing somatotrophs with deeply stained cytoplasm (arrows).X1000.

Fig.5: An electron micrograph of a somatotroph cell at 15 days-old female rats showing the cytoplasm packed with numerous secretory granules, ill-distinct organelles. Notice euchromatic nucleus with prominent two nucleoli (arrows). X12000.

Fig.6: A photomicrograph of pars distalis of 22 daysold female rats showing numerous and largesized somatotrophs grouped in cords surrounding blood capillary $(\mathrm{S})$, some of them were deeply stained (arrows) while others were faintly stained (arrowheads). PASOrange G stain, X1000.

Fig.7: An electron micrograph of somatotrophs at 30 days-old female rats showing sparsely granulated cells with electron lucent cytoplasm, well developed dilated cisternae of RER (R), numerous mitochondria (m); a heavy granulated cell with electron dense cytoplasm and ill-distinct organelles. Notice, both cell types facing the blood capillary.X8000.

Fig.8: A photomicrograph of pars distalis at 40 daysold female rats stained with PAS-Orange G showing most of somatotrophs were deeply stained.X1000

Fig.9: An electron micrograph of somatotrophs at 40 days-old female rats showing the cytoplasm packed with numerous electron dense secretory granules obscuring most of organelles.X6000

Fig.10: A photomicrograph of pars distalis of adult female rats (4 months-old) stained with PASOrange $G$ showing hypertrophied somatotrophs with faintly stained cytoplasm (arrows).X 1000.

Fig.11: An electron micrograph of sparsely granulated somatotroph cell of adult female rat (4 months-old) showing electron lucent cytoplasm with numerous well-developed dilated cisternae of RER (R), mitochondria (m) and euchromatic nucleus (N).X11000

Fig.12: A photomicrograph of pars distalis of senile female rats (2 years-old) stained with PASOrange $G$ showing degenerated, small-sized somatotrophs (arrowheads) while others showed vacuolated cytoplasm with ill-distinct cell boundaries (an arrow). X1000.

Fig.13: An electron micrograph of a somatotroph cell of senile female rat showing few, small-sized secretory granules (arrows), swollen mitochondria (m), highly dilated and destructed RER (R). X1000.

Table 1: Showing results of the number of somatotrophs in different postnatal ages of female rats (5animals / age).

\begin{tabular}{|c|c|c|}
\hline Age & No. of animals / age & No. of somatotrophs/ $x 400$ field \\
\hline At birth & 5 & $14.52 \pm .806^{\mathrm{b}, \mathrm{c}, \mathrm{d}, \mathrm{e}, \mathrm{f}, \mathrm{g}, \mathrm{h}, \mathrm{i}, \mathrm{j}}$ \\
\hline 7 days & 5 & $18.96 \pm .756^{\mathrm{a}, \mathrm{c}, \mathrm{d}, \mathrm{e}, \mathrm{f}, \mathrm{g}, \mathrm{h}, \mathrm{i}, \mathrm{j}}$ \\
\hline 15 days & 5 & $25.80 \pm .879^{\mathrm{a}, \mathrm{b}, \mathrm{d}, \mathrm{e}, \mathrm{f}, \mathrm{g}, \mathrm{h}, \mathrm{i}}$ \\
\hline 22 days & 5 & $32.06 \pm .918^{\mathrm{a}, \mathrm{b}, \mathrm{c}, \mathrm{e}, \mathrm{f}, \mathrm{g}, \mathrm{h}, \mathrm{i}, \mathrm{j}}$ \\
\hline 30 days & 5 & $40.50 \pm 1.648^{\mathrm{a}, \mathrm{b}, \mathrm{c}, \mathrm{d}, \mathrm{h}, \mathrm{i}, \mathrm{j}}$ \\
\hline 40 days & 5 & $40.42 \pm 1.719^{\mathrm{a}, \mathrm{b}, \mathrm{c}, \mathrm{d}, \mathrm{h}, \mathrm{i}, \mathrm{j}}$ \\
\hline 2 months & 5 & $41.24 \pm 1.406^{\mathrm{a}, \mathrm{b}, \mathrm{c}, \mathrm{d}, \mathrm{h}, \mathrm{i}, \mathrm{j}}$ \\
\hline 4 months & 5 & $72.64 \pm 2.249^{\mathrm{a}, \mathrm{b}, \mathrm{c}, \mathrm{d}, \mathrm{e}, \mathrm{f}, \mathrm{g}, \mathrm{j}}$ \\
\hline 6 months & 5 & $70.98 \pm 2.718^{\mathrm{a}, \mathrm{b}, \mathrm{c}, \mathrm{d}, \mathrm{e}, \mathrm{f}, \mathrm{g}, \mathrm{j}}$ \\
\hline 2 years & 5 & $25.76 \pm 1.265^{\mathrm{a}, \mathrm{b}, \mathrm{d}, \mathrm{e}, \mathrm{f}, \mathrm{g}, \mathrm{h}, \mathrm{i}}$ \\
\hline
\end{tabular}

The data are given as means \pm standard error (SE), with dissimilar superscript letters (significantly differ at $p<0.05$ ): (a) letter is significantly differing from birth value; (b) letter is significantly differing from 7 days old; (c) letter is significantly differing from 15 days old value;(d) letter is significantly differing from 22 days old value;(e) letter is significantly differing from 30 days old value;(f) letter is significantly differing from 40 days old value; (g ) letter is significantly differing from 2 months old;(h) letter is significantly differing from 4 months old value;(i) letter is significantly differing from 6 months old value; (j) letter is significantly differing from 2 years old value. 


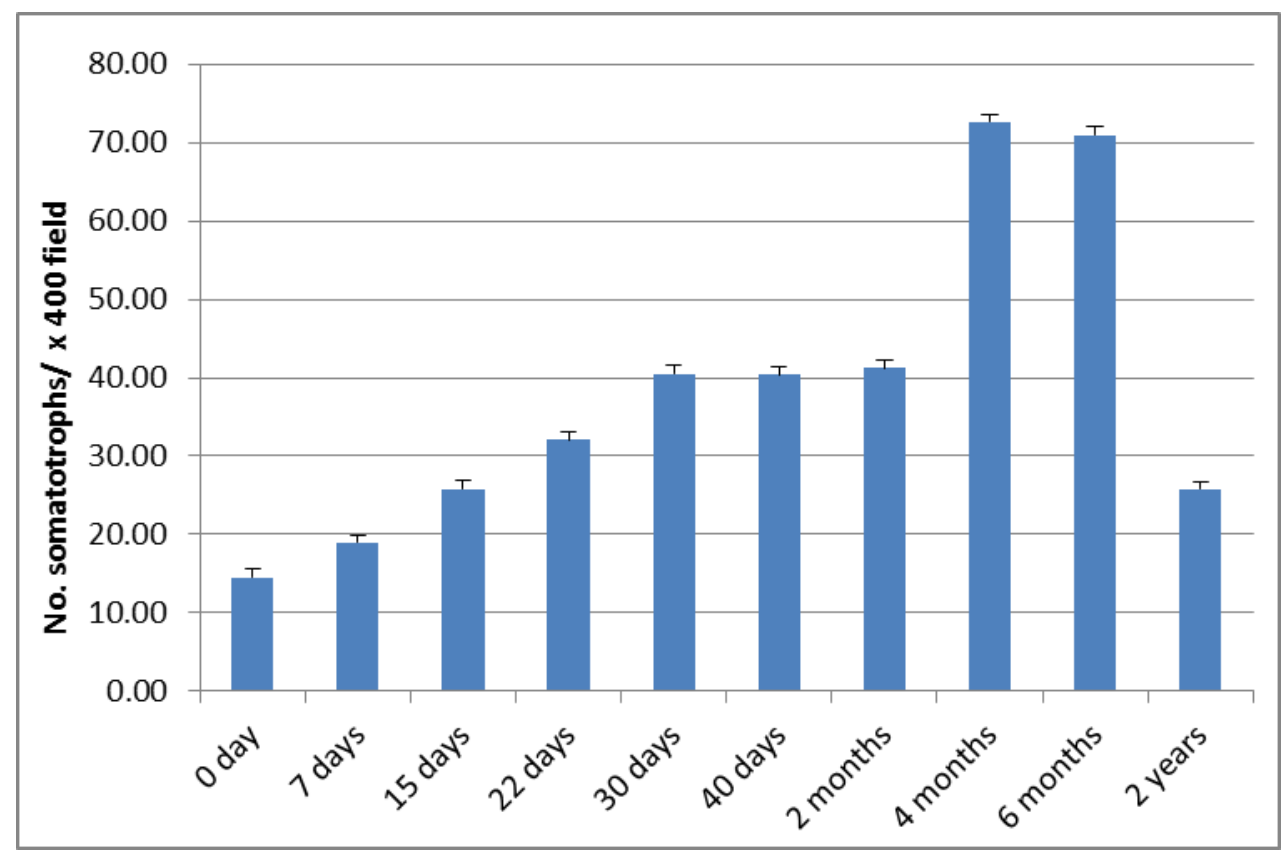

Fig.14: showing the relation between the number of somatotrophs at the different postnatal ages of female rats. The task performance was assist using number of somatotrophs / X 400 field. Bars on columns represent SE of the mean.

\section{DISCUSSION}

Somatotrophs were one of the acidophilic cells present in the pars distalis of different domestic animals which secrete growth hormone (Eurell and Frappier 2006). They react positive with histochemical stain PAS-Orange $G$ and give yellowish orange stained cytoplasmic granules. The density of color depends on the amount of granules located (Baker, 1970 and Pearse, 1980). Also, they could be identified ultrastructurally by the characteristic large (300-500 $\mathrm{nm}$ in diameter), rounded and uniform electron dense secretory granules as recorded by (Nakane, 1970).

The present study showed the morphological and morphometric age-related changes in somatotrophs of postnatal female rats. They appeared in the first week of postnatal life as sporadic cells with prominent mitosis. Sasaki (1988) suggested that the increase in numbers of most of anterior pituitary cells specially somatotrophs was due to the cell division by mitosis. Also, the observed somatotrophs in our work showed signs of inactivity which regarded by faint staining cytoplasm with PAS-Orange $G$ and presence of sparse secretory granules associated with poorly developed cytoplasmic organelles ultrastructurally. This finding agreed with that reported by Yamashita (1969) who stated that somatotrophs were poorly developed in newborn and during the first 10 days postnatally but showed steady increase in number by mitosis. While, Wilson and Christensen (1980) found that prominent somatotrophs with well-developed organelles at birth. Consistent with our result, Sun et al. (2002) stated that serum growth hormone concentration decline abruptly immediately after birth.

At the $2^{\text {nd }}$ week of postnatal life (15 days-old rats), we observed moderate increase in numbers of somatotrophs with marked granulation which manifested by densely stained cytoplasm after PASOrange $G$ used. Also by electron microscopy, the cytoplasm packed with secretory granules which obscuring most of cytoplasmic organelles. According to our observation, we suggested that somatotrophs became active which appeared in synthetic and storage phases. Similarly, Wilson (1986) reported that the 14 days postnatally considered as crucial age to detect if the mice will be normal or dwarf as it showed negative reaction to anti-GH.

It has been found that progressive increase in number of somatotrophs and grouped in cords surrounding blood capillaries at 22-30 days postnatally as recorded by Sasaki (1988). While Gulyás et al. (1993) stated that somatotrophs reached plateau between p $13 \&$ p 20 followed by decreasing on day p35. We investigated that during this age, somatotrophs became active and secretory which manifested ultrastructurally by presence of electron lucent cytoplasm, sparsely granulated associated with numerous of well-developed organelles as dilated cisternae of RER and mitochondria. Similar observations were recorded by Wilson and Christensen (1980) and Sasaki (1988). Our results indicate that both synthesis and release of growth 
hormone are enhanced as the animal approaches puberty. The level of growth hormone gradually rises postnatal and became significant between ages 26-30 days (Eden et al., 1978). Changes in circulating growth hormone concentration in young pigs are caused by increase the total number of somatotrophs (Lee et al., 2004).

At pubertal age (40-days old rats), we showed no significant changes in number of somatotrophs compared with ages of 30 days and 2 months and most of them appeared in storage phase. Most of them were repacked with secretory granules. Our findings were coincided with that recorded by Sasaki (1988) who stated that temporary slowing of somatotroph development around the puberty. Some researches recorded that the ovary has a role in somatotrophs differentiation. During the postnatal life, the ovary stimulates the differentiation of lactotrophs and inhibits that of somatotrophs. Also, ovariectomy before puberty induced increasing of somatotrophs to about $50 \%$ of the cell population while after puberty had less marked effect (Sasaki and Sano, 1980). The growth hormone secretion is progressively declined beginning in the adult life a phenomenon termed somatopause (Beatriz et al., 2001, Hoffman et al., and Lieberman \& Hoffman 1997).

After puberty (2 months-old rats), our results showed marked increase in number of somatotrophs reaching maximum in the adults (4-6 months) compared to immature ages as recorded by Sasaki (1988). Accordingly, the plasma growth hormone reached the maximum level after puberty (Ojeda and Jameson, 1977) at time at which estrogen was also elevated (Parker and Mahesh, 1976). Some researchers suggested that estradiol may have a role in the regulation of GH secretion by modulating GRF release and acting directly on the somatotrophs (Shirasu et al., 1999). It may be assumed that the ultrastructural features of somatotrophs at this age correlate with their functional activation which exhibited by presence of numerous and well developed organelles.

In aged rats, our morphometrical results revealed a significant decline in the number of somatotrophs compared with other postnatal ages and reached to the level of 15 days-old rats. Such number decreasing was associated with appearance of regressive changes in somatotrophs with losing the typical structure as regarded by decreasing in granulation, vacuolation in cytoplasm with ill- distinct cell boundaries as well as highly dilatation and destruction of mitochondria and RER. Therefore, such findings lead us to suggest somatotrophs were affected by age advancement. Our results were in agreement with that recorded by Abdl-Maksoud and Moustafa (2003), Takanashi et al. (2001), and Shinaki et al. (1995). They reported that somatotrophs are the most sensitive cells with aging process associated with a reduction in their number and subsequent decline in growth hormone secretion. Jurado et al. (1998) recorded that this reduction was clearly more marked in senescent female than males and their ultrastructure changes suggestive of an immature state. The reduction of growth hormone with aging occurred either as a result of impairment in pituitary responsiveness to GHRH (Ceda et al., 1986) or reduction in the pulsatile secretion of growth hormone in old rats (Sonntag et al., 1983). Moreover, the pituitaries of older ages seem to be more sensitive to the inhibitory effects of somatostatin (GIH) (Spik and Sonntage, 1989). All the previous causes were attributed to intrinsic lesion in somatotrophic cells in aging animals (Müller et al., 1993).

In conclusion, there was a significant postnatal agerelated change in the structure and number of somatotrophs in female rats.

\section{REFERENCES}

Abd El-Maksoud, S.A. and Moustafa, M.A. (2003): Age-related changes in the pars distalis of the pituitary gland of female albino rats and the possible role of honey: light and electron microscopic study. AAMJ, Vol.1, N. 3, September.

Anderson, L.; Jeftinija, S. and Scanes, C. (2004): Growth Hormone Secretion: Molecular and Cellular Mechanisms and In Vivo approach. Exp Biol Med 229: 291-302.

Baker, B.L. (1970): Studies on hormone localization with emphasis on the hypophysis. Hitochem. \& Cytochem. J. 18(1): 1-8.

Bancroft, J. and Gamble, M. (2008): "Theory and practice of histological techniques. 6th Ed., Churchill-Livingstone, Edinburgh, London, Melbourne, New York.

Beatriz, V.; Lucinda, C.; Elvira, M.; Gumersindo, F. and Franco, $S-F$. (2001): Sensitivity to exogenous $\mathrm{GH}$ and reversibility of the reduced IGF-I gene in aging rats. European journal of endocrinology 145: 73-85.

Ceda, G.; Valenti, G.; Butturini, U. and Hoffman, A. (1986): Diminished pituitary responsiveness to growth hormone-releasing factor in aging male rats. Endocrinology 118: 2109-2114.

Eden, S.; Albertsson-Wikland, K. and Isaksson, $O$. (1978): Plasma levels of growth hormone in female rats of different ages. Acta Endocrinologica 88. 676-690.

Eurell, J. and Frappier, B. (2006): Dellman's text book of veterinary histology $6^{\text {th }}$ Edition.

Garcia-Tornadu, I.; Risso, G.; Perez Millan, M.; Millan, M.; Noain, D.; DiazTorga, G.; Low, M.; Rubinstein, M. and Becu- Villalobos, D. 
(2010): Neurotransmitter modulation of the GHRH-GH axis. Front Horm Res 38: 59-69.

Gulyás, M.; Ács, Z; Rappay, G. and Makara, G. (1993): Corticotroph, somatotroph and mammotroph cell kinetics in the postnatal infant female rat. Histochemistry and Cell Biology, 100: 503-507.

Hayat, M. (1986): Basic technique for transmission electron microscope. 2nd Ed. Academic Press, Baltimore.

Hoffman, A.; Lieberman, S.; Butter field, G.; Thompson, J.; Hintz, R.; Ceda, G. and Mocus, $R$. (1997): Functional consequences of the somatopause and its treatment, Endocrine Aug, 7(1): 73-76.

Jurado, S.; Cónsole, G. and Gomez Dumm, C. (1998): Sexually Dimorphic Effects of Aging on Rat Somatotroph Cells. An Immunohistochemical and Ultrastructural Study. J. Vet. Med. Sci. 1998 Jun; 60(6): 70511.

Lee, J. (2006): Comparative study of immunocytochemical patterns of somatotrophs, mammotrophs, and mammosomatotrophs in the porcine anterior pituitary. Retrospective Theses and Dissertations. Paper 1875.

Lee, J.; Jeftinija, K.; Jeftinija, S.; Stromer, M.; Scanes, C. and Anderson, L. (2004): Immunocytochemical distribution of somatotrophs in porcine anterior pituitary. Histochem Cell Biol, 122: 571577.

Lieberman, S. and Hoffman, A. (1997): The somatopause: Should growth hormone deficiency in older people be treated? Clin Geriat Med NOV; 13(4): 671-684.

Melmed, S. (2002): The Pituitary. Malden, MA: Blackwell Science Inc., pp., 419-454.

Müller, E.; Cella, S.; De Germano Colonna, V.; Parenti, M.; Cocchi, D. and Locatelli, V. (1993): Aspects of neuroendocrine control of growth hormone secretion in aging mammals. J. Reprod Fertil. (Suppl.,) 46: 99-114.

Müller, E.; Locatelli, V. and Cocchi, D. (1999): Neuroendocrine control of growth hormone secretion. Physiol Rev 79: 511-607.

Nakane, P.K. (1970): Classifications of anterior pituitary cell types with immunoenzyme histochemistry. J. Histochem \& Cytochem, 18 (1): 9-20.

Ojeda, R. and Jameson, H. (1977): Developmental Patterns of Plasma and Pituitary Growth Hormone $(\mathrm{GH})$ in the Female Rats. Endocrinology, (100)

Parker, C. and Mahesh, V. (1976): Hormomal events surrounding the natural onset of puberty in female rats. Biol. Reprod. 14: 347-353.

Pearse, A. (1980): Histochemistry, theoretical and applied, preparative and optical technology. $4^{\text {th }}$ Ed. Chruchill, Livingstone, Edinburgh, London, New York.

Reynolds, E. (1963): The use of lead citrate at high $\mathrm{pH}$ as an electron opaque stain in electron microscopy. J. Cell Biol., 17: 208-212.

Richardson, K.; Jarett, L. and Finak, E. (1960): Embedding in epoxy resins for ultra-thin sectioning in EM Stain Technol. 35: 313-323.

Sasaki, F. (1988): Changes with age in the number and size of anterior pituitary cells in female mice from suckling to adulthood. $\mathbf{J}$. Endocrinol 117, 5-10.

Sasaki, F. and Sano, M. (1980): Role of the ovary in the sexual differentiation of prolactin and growth hormone cells in the mouse adenohypophysis during postnatal development: a stereological morphometric study by electron microscopy. Journal of Endocrinology 85, 283-298.

Sasaki, F. and Sano, M. (1986): Role of the arcuate nucleus and ovary in the maturation of growth hormone, prolactin, and non-granulated cells in the mouse adenohypophysis during postnatal development: a stereological morphometric study by electron microscopy. Endocrinology 119, 1682-1689.

Shimokawa, I.; Yu, B.; Higami, Y. and Ikeda, T. (1996): Morphometric analysis of somatotrophs: Effects of age and dietary restriction Neurobiology of aging, Vol.17, No.1, 79-86.

Shinkai, T.; Sakurai, Y. and Ooka, H. (1995): Agerelated changes in the numbers of mammotrophs, somatotrophs and mammosomatotrophs in the anterior pituitary gland of female rats: a flow cytometric study. Mech Aging Dev. Sep.15.83 (3) 125-131.

Shirasu, K.; Stupf, W. and Sar, M. (1999): Evidence for direct action of estradiol on growth hormone-releasing factor (GRF) in rat hypothalamus: localization of $[3 \mathrm{H}]$ estradiol in GRF neurons. Endocrinology, 127 (1): 344349.

Sonntag, W.; Hylka, V. and Meites, J. (1983): Impaired ability of old male rats to secrete $\mathrm{GH}$ in a vivo but in vitro in response to hpGRF (144). Endocrinology 113: 2305-2307.

Spik, K. and Sonntage, W. (1989): Increased pituitary response to somatostatin in aging male rats: relationship to somatostatin receptor number and affinity. Neuroendocrinology 50: 489494

Sun, H.; Anderson, L.; YU, T.; Kim, K.; Klindt, J. and Tuggle, C. (2002): Neonatal Meishan pigs show POU1F1 genotype effects on plasma $\mathrm{GH}$ and PRL concentration. Anim Reprod Sci 69: 223-237.

Takahashi, S. and Kawashima, S. (1982): Agerelated changes in prolactin cell percentage and serum prolactin levels in intact and 
neonatally gonadectomized male and female rats. Acta Anatomica 113, 211-217.

Takanashi, R.; Sugawara, O. and Mernyei, M. (2001): Decrease growth hormone secreting cells of hypophysis in senile cachexia. Rinsho Byori. 49(1): 61-65.

Wilson, D. (1986): Immunocytochemical analysis of somatotrophs and mammotrophs in the pars distalis of postnatal dwarf (dw) mutant mice. Cell Tissue Res. 243: 561-565.
Wilson, D. and Christensen, E. (1980): Postnatal development of somatotrophs and mammotrophs in the pars distalis of C57BL mouse. Cell Tissue Res. 211, 441-448.

Yamashita, K. (1969): Electron microscopic observations on the postnatal development of the anterior pituitary of the mouse Gunma Symp Endocrinol 6: 177-196.

\section{دراسات سيتولوجية وقياسية على الخلايا الحاثة للنمو فى الجزء القاصى للغدة النخامية أثناء مرحلة ما بعد الولادة

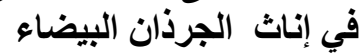

E-mail: $\underline{\text { tagh mhm@yahoo.com Assiut University web-site: www.aun.edu.eg }}$

اجريت هذه الدر اسة لتوضيح التغير ات التركيبية والكمية على الخلايا الحاثة للنمو فى الغدة النخامية (الجزء القاصى) لاناثاث الجرذان

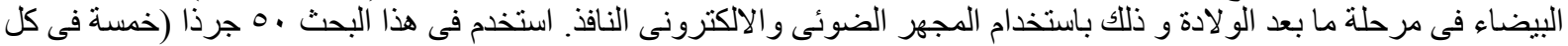

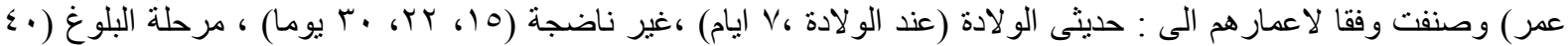

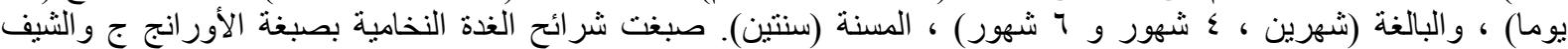

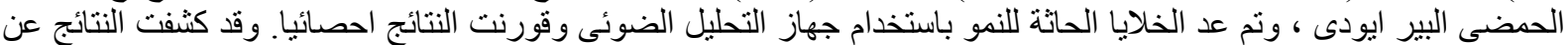

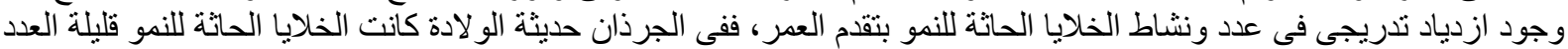

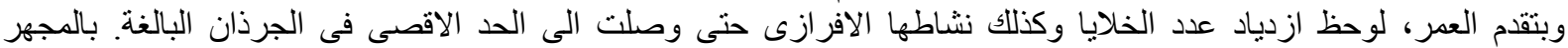

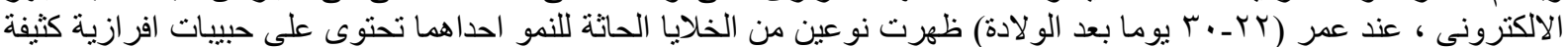

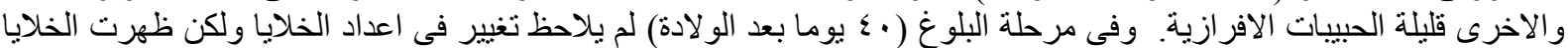

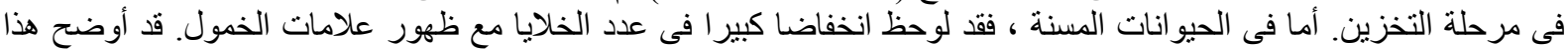

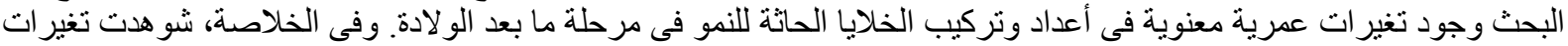

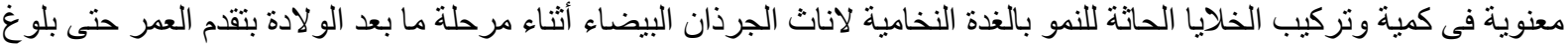
سن الثيخوخة. 